\title{
Wstęp
}

\section{Wojna, trauma i kultura}

Marta Zielińska

TEKSTY DRUGIE 2018, NR 4, S. 7-11

DOI: $10.18318 /$ td.2018.4.1

$\mathbf{T}$

ematem numeru jest kulturowe upamiętnianie traumatycznych doświadczeń pierwszej wojny światowej, zwłaszcza tych, które w ciągu stulecia od zakończenia walk nie znalazły miejsca w oficjalnych narracjach, składających się na istniejący w zbiorowej świadomości bilans tego wydarzenia. Artykuły w przeważającej części skupiają się na Europie Zachodniej, co jest oczywiste, gdyż tamtejszy teatr wojny pozostał dla wszystkich jej głównym symbolem.

Oswajanie, a przez to unieszkodliwianie traum indywidualnych i zbiorowych było od zarania ludzkości jednym z najważniejszych zadań kultury. W wymiarze transcendentalnym służyły temu religie i mitologie, w doczesnym - rytuały, obyczaje, przesądy i przysłowia. A także sztuka i literatura. Życie w epoce przednowoczesnej toczyło się "na padole łez" - pełne bólu i zagrożeń ze strony natury, wrogów, chorób deformujących i degradujących ciało. Zawarta w wierzeniach świadomość wygnania z raju, przeminięcia „złotego wieku” godziła jednak ludzi z ich trudną kondycją. Rozwój naukowy i cywilizacyjny, przypieczętowany z końcem XVIII wieku nastaniem ery nowoczesności, odkrył racjonalne podłoże cierpień i nieszczęść człowieka i stopniowo dzięki wiedzy niwelował ich zasięg oraz skutki, unieważniając zarazem dawne uroszczenia religii i przesądów. Tym

\section{Marta Zielińska}

- dr hab., kieruje Pracownią Romantyczną IBL PAN, historyk literatury, edytor, varsavianistka. Opublikowała m.in. Opowieść o Gustawie iMaryli czyli teatr, życie i literatura (1989, 1998), Warszawa, dziwne miasto (1995), Kapliczki Warszawy (1991), Polacy, Rosjanie, romantyzm (1998), [współaut.] Mickiewicz. Encyklopedia (2001, 2010), Pogoda w czasach romantyków (2017), Granice (2018). 
sposobem traumatyczne doświadczenia, trwale dotąd wpisane w los ludzki, zaczęły się alienować w nowym systemie kultury, cierpienie spychano na margines głównego nurtu jako egzystencjalny skandal, wymagający specyficznego traktowania. U progu XIX stulecia, kiedy rozpoczynała się tzw. druga rewolucja naukowa, karty literatury romantycznej zaludnił legion szaleńców, których męce dawna kultura pomóc już nie mogła, co streszczała słynna wymiana zdań między księdzem i Pustelnikiem-Gustawem w IV cz. Dziadów ("- Znasz ty Ewangeliją? - A znasz ty nieszczęście?”). Oprócz traum indywidualnych, wynikających z buntu młodych wobec zasad starego moralnego porządku, w Polsce dołączyła trauma po upadku ojczyzny, powołująca do życia zastęp patriotów wariatów.

Choroby generowane przez wojnę opisał w Pamiętnikach (na podstawie odwrotu wojsk napoleońskich spod Moskwy) profesor medycyny Uniwersytetu Wileńskiego Józef Frank. Poza całą listą infekcji uczony dostrzegł także przypadki „porażenia układu nerwowego" u ofiar urazów psychicznych spowodowanych wojennymi przeżyciami. Dama, której podczas walk spalono dwór, upadła zemdlona, a w następstwie szoku straciła mowę i łatwość połykania, co później całkiem uniemożliwiło jej jedzenie i zmarła. Stary polski generał na wieść o definitywnej klęsce Napoleona zapadł w siedmiodniowy letarg i „obudził się, ale zupełnym idiotą", młoda litewska panienka natomiast zemdlała, gdy jej dom naszli francuscy maruderzy i sterroryzowali ojca bronią; od tego czasu codziennie w porze tamtego zdarzenia zapadała w stan somnambuliczny, odgrywając scenę, która ją wówczas przeraziła'.

Kultura XIX wieku jednak jeszcze radziła sobie z wojennymi traumami. Europejskie rewolucje i regionalne wojny toczone tradycyjnymi metodami wpisywały się w coraz powszechniejsze narodowe i społeczne aspiracje różnych grup; w dobie rozwoju przemysłu i komunikacji ludzi nie łączyła już więź ściśle lokalna, lecz terytorium całego państwa, etniczne pochodzenie lub klasa społeczna. W imię tych wartości wielu było gotowych do cierpienia, a nawet śmierci, gdyż rekompensowała je satysfakcja z osiągniętego celu. Przegrani koili szok porażki marzeniami o odwecie. Wszystkich męczenników uwznioślała literatura i malarstwo, zapewniając społeczną akceptację tym, których despotyczne rządy skazywały na więzienie czy banicję.

Pierwsza wojna światowa domknęła wiek XIX. Z mapy Europy zniknęły dominujące monarchie, na ich miejscu wyłoniły się państwa narodowe, demokratyczne, ale ze swoimi partykularnymi interesami. Ta wojna właściwie nie powinna była wybuchnąć. Wszak w Europie panowała wówczas między mocarstwami równowaga sił technicznych i demograficznych zasobów, od dziesięcioleci wzmacniały się ruchy pacyfistyczne,

1 Zob. J. Frank Pamiętniki, z francuskiego przetłumaczył, wstępem i uwagami opatrzył W. Zahorski, t. 3, Wilno 1913, s. 71-74. 
zwieńczone powstaniem Ligi Pokoju i ustanowieniem Pokojowej Nagrody Nobla, polityczną stabilizację zapewniały dwa silne bloki państw gwarantujących sobie wzajemne bezpieczeństwo. Lecz niezawodny, wydawałoby się, ówczesny system sojuszy nie wytrzymał kryzysu po zamachu w Sarajewie - zadziałał mobilizująco, a nie odstraszająco: po naruszeniu jednego ogniwa nastąpiły kolejne wypowiedzenia wojny i pokój posypał się jak kostki domina, rozbity przez partykularyzmy ekonomiczne i narodowe. Równowaga sił nie pozwoliła zarazem szybko wyłonić zwycięzcy, linie frontów wyznaczone okopami przez długie miesiące nie zmieniały położenia, a o wygranej w tej sytuacji decydowały zasoby amunicji oraz rezerwy demograficzne walczących stron, niezbędne, by nowymi rekrutami zastępować ginących tysiącami obrońców utrzymywanych wielkim kosztem pozycji. Była to strategia na wyniszczenie przeciwnika. Wygraną ententy przypieczętowało przystąpienie Stanów Zjednoczonych, które dostarczyły świeżych sił, niezmęczonych wieloletnią walką.

Społeczeństwa zachodniej Europy wyszły z wojny z wielką traumą okopów, przypominających jatki, gdzie pod ostrzałem i gazami poległy w męczarniach miliony, a kolejne miliony zostały trwale okaleczone. Żołnierz w tej pierwszej nowoczesnej wojnie został uprzedmiotowiony, sprowadzony do roli mięsa armatniego, żywego trybiku w wojennej machinie śmierci, szybko zużywanego i wymienianego, zatracając poczucie własnej tożsamości i sensu prowadzonej walki.

Doświadczenia wschodniej Europy były nieco odmienne. Fronty bardziej rozciągnięte, mniej stabilne, załamywały się szybciej, ponadto wojna uaktywniła aspiracje narodowe i społeczne poddanych ludów, rozsadzając wielkie monarchie od wewnątrz, walka zatem nie wydawała się pozbawiona sensu, co potwierdziły potem traktaty pokojowe. A przy tym już po podpisaniu pokoju trwały na tych ziemiach krwawe starcia między nowymi państwami o kształt ich granic.

Trauma Wielkiej Wojny nie została dostatecznie przepracowana w okresie dwudziestolecia. Dominowały dwie narracje. Pierwsza, jeszcze XIX-wieczna - estetyzująca i heroiczna, gloryfikowała militarny wysiłek narodów, druga ekspresjonistyczna, w której znalazły wyraz wojenne potworności, dotykające żołnierzy w okopach, stanowiła artystyczne oręże pacyfistów ${ }^{2}$.

Zofia Nałkowska mawiała, że „każda wojna wydaje się być ostatnią, każda następna niemożliwą"3. Pisarka już w sierpniu 1914 roku rozumiała, jak wojna prowadzona

2 Pisze o tym Maria Janion w rozprawie Wojna i forma, w: Literatura wobec wojny i okupacji, red. M Głowiński i J. Stawiński, ,Z Dziejów Form Artystycznych w Literaturze Polskiej,', t. 43, Zakład Narodowy im. Ossolińskich, Wrocław 1976.

3 N. Drucka Wspomnienia o Zofii Nałkowskiej, w: Wspomnienia o Zofii Nałkowskiej, red. W. Barcikowski i in., Czytelnik, Warszawa 1965, s. 141. 
w imię heroicznej propagandy rządzących destruuje życie zwykłych ludzi - rannych, zmęczonych śmiertelnie żołnierzy tęskniących za dalekim domem, bezbronnych cywilów atakowanych w miastach bombami i artylerią, rodzin pozbawionych żywicieli. Dlatego przeciwna była zawsze ideologii narodowej i bohaterskiej jako spoiwa zbiorowości ${ }^{4}$. W dwudziestoleciu polski pacyfizm miał różne odcienie. Od Józefa Wittlina, dopuszczającego przemoc w obronie najcenniejszych dla człowieka wartości - po Antoniego Słonimskiego, do końca racjonalnie wierzącego, że walka piórem przeciwko agresji przynosi rezultaty5. Słonimski trwał optymistycznie na posterunku kronikarza do ostatniego numeru „Wiadomości..., który wyszedł 3 września 1939 roku. W komentarzu do opublikowanego po latach książkowego wydania Kronik poeta pisał:

Ostatnie kilkanaście Kronik cechuje wciąż jeszcze poczucie wykonywania obowiązku zwalczania wpływów hitlerowskich i walka obsesyjna z antysemityzmem, ale jest w nich poczucie normalności, pewność granic nieprzekraczalnych, niewiara w możliwość wybuchu wojny. Nie wierzyłem w wojnę jeszcze tego pierwszego ranka. Dopiero, gdy otworzyłem radio i usłyszałem słowa „Uwaga, uwaga, przeszedł, Koma trzy”, "Ogłaszam alarm dla miasta Warszawy". Poczułem lęk i rozpacz, że mój świat się na tych słowach skończył. ${ }^{6}$

Ówczesne oswajanie traumy zawiodło. Pacyfizm objął przede wszystkim społeczeństwa dawnej ententy, natomiast przegrani Niemcy uraz wojenny skanalizowali w polityce odwetu i zmycia hańby. Pierwsza strategia odwoływała się do poczucia strachu przed nową hekatombą, druga - do zakorzenionych od zawsze pierwotnych odruchów człowieka, kompensującego porażkę agresją. W efekcie lęk przed następną wojną dyktujący politykę ustępstw wobec III Rzeszy rozzuchwalił agresora.

Zbiurokratyzowane, uprzemysłowione ludobójstwo na skalę dotąd niespotykaną, jakie dokonało się podczas drugiej wojny światowej, zwróciło szczególną uwagę badaczy na sposoby konstruowania kulturowej pamięci o traumatycznych wydarzeniach i doświadczeniach. Formy pamięci bowiem, czego dowiodła historia dwóch wojen światowych, nie były niewinne, niektóre okazały się w dalszej perspektywie groźne, generujące kolejne nawroty przemocy.

4 Nałkowska wielokrotnie komentuje pierwszą wojnę w swoich dziennikach, zwłaszcza w latach 1914-1915.

5 Zob. polemikę obu autorów w „Wiadomościach Literackich”: J. Wittlin Ze wspomnień byłego pacyfisty , „Wiadomości Literackie" 1930, nr 1 i odpowiedź A. Słonimskiego w Kronice tygodniowej następnego numeru.

6 A. Słonimski Kroniki tygodniowe 1936-1939, wstęp i przyp. R. Habielski, LTW, Warszawa 2004, s. 393. 
Czy dziś, w epoce ponowoczesnej, zmiennej, niestabilnej, zglobalizowanej, cyfrowej, kultura udźwignie zadania reprezentacji traum dawnych i tych świeżych, tak by umiały rozbroić ukryty w nich destrukcyjny potencjał? W niniejszym numerze mamy omówione szczegółowe przykłady współczesnych prób przedefiniowania traum pierwszej wojny, którym przyświeca ten właśnie cel. Drogą do tego celu jest m.in. „odpolitycznienie pamięci narodowej i rewizjonizm historyczny" (Piątek) oraz "podważenie narracji heroicznej i patriotycznej, obnażanie manipulacji politycznych, identyfikacja z żołnierzem jako ofiarą - nie tyle wroga, co niekompetencji przywódców i bezwzględnych kalkulacji spekulantów wojennych" (Lorek). Doświadczenia traumy pierwszej wojny w zachodniej Europie są dobrym materiałem do takich refleksji i badań, gdyż ze względu na czasowe oddalenie stanowią obraz czysty, dający się sprowadzić do przeżyć egzystencjalnych, nieuwikłanych w aktualne spory i resentymenty, jakie towarzyszą jeszcze drugiej wojnie.

Historia postępu technicznego i cywilizacyjnego jest zarazem historią cierpień wcześniej nieznanych, na które kultura nie jest przygotowana, toteż warto śledzić próby prowadzące do odpowiedzi na pytanie, czy możliwy jest projekt kultury w bezpieczny sposób neutralizujący zbiorowe traumy.

\section{Abstract}

\section{Marta Zielińska}

THE INSTITUTE OF LITERARY RESEARCH OF THE POLISH ACADEMY OF SCIENCES (WARSAW)

War, Trauma and Culture

Zielińska outlines the history of the cultural forms of war trauma in the modern era, from Romanticism until World War II. Against this backdrop, the authors represented in this issue argue, the postmodern era appears as clearly distinct in terms of its strategies of commemorating the victims of World War l.

\section{Keywords}

war traumas, forms of memory, World War I, pacifism 